\title{
Molecular chaperones: guardians of the proteome in normal
}

\section{and disease states [version 1; peer review: 2 approved]}

\author{
Wilson Jeng ${ }^{1}$, Sukyeong Lee ${ }^{1}$, Nuri Sung ${ }^{1}$, Jungsoon Lee ${ }^{1}$, Francis T.F. Tsai ${ }^{1-3}$ \\ ${ }^{1}$ Verna and Marrs McLean Department of Biochemistry and Molecular Biology, Baylor College of Medicine, Houston, TX, USA \\ 2Department of Molecular and Cellular Biology, Baylor College of Medicine, Houston, TX, USA \\ ${ }^{3}$ Department of Molecular Virology and Microbiology, Baylor College of Medicine, Houston, TX, USA
}

V1 First published: 15 Dec 2015, 4(F1000 Faculty Rev):1448

https://doi.org/10.12688/f1000research.7214.1

Latest published: 15 Dec 2015, 4(F1000 Faculty Rev):1448

https://doi.org/10.12688/f1000research.7214.1

\section{Open Peer Review}

Approval Status

1

2

version 1

15 Dec 2015

Faculty Reviews are review articles written by the prestigious Members of Faculty Opinions. The articles are commissioned and peer reviewed before publication to ensure that the final, published version is comprehensive and accessible. The reviewers who approved the final version are listed with their names and affiliations.

1. Jose Barral, University of Texas Medical Branch, Galveston, USA

2. Hays Rye, Texas A\&M University, College Station, USA

Any comments on the article can be found at the end of the article.
Keywords

molecular chaperones, chaperones, proteases, protein folding, misfolding, aggregation, ATP-dependent molecular chaperones 
Corresponding author: Francis T.F. Tsai (ftsai@bcm.edu)

Competing interests: The authors declare there were no competing interests.

Grant information: Research in the Francis T.F. Tsai and Sukyeong Lee laboratory is supported by grants from the National Institutes of Health (R01-GM111084 and R01-GM104980) and the Robert A. Welch Foundation (Q-1530).

The funders had no role in study design, data collection and analysis, decision to publish, or preparation of the manuscript.

Copyright: ( $) 2015$ Jeng W et al. This is an open access article distributed under the terms of the Creative Commons Attribution License, which permits unrestricted use, distribution, and reproduction in any medium, provided the original work is properly cited.

How to cite this article: Jeng $\mathrm{W}$, Lee $\mathrm{S}$, Sung $\mathrm{N}$ et al. Molecular chaperones: guardians of the proteome in normal and disease states [version 1; peer review: 2 approved] F1000Research 2015, 4(F1000 Faculty Rev):1448

https://doi.org/10.12688/f1000research.7214.1

First published: 15 Dec 2015, 4(F1000 Faculty Rev):1448 https://doi.org/10.12688/f1000research.7214.1 


\section{Introduction}

The vast majority of proteins must fold correctly in order to gain functional activity. While the protein folding information is encoded within the nascent polypeptide chain, newly synthesized polypeptides (or those imported into organelles) are prone to misfolding, causing aggregation and formation of other toxic species ${ }^{1}$. Consequently, maintaining protein homeostasis (proteostasis) is essential for cell and organismal health ${ }^{2}$. To accomplish this, cells have evolved a sophisticated network of protein quality control machines, consisting of molecular chaperones and proteases, which monitor the folding of proteins and their assembly into functional complexes, and selectively remove excess and damaged proteins from the cell. Challenging the capacity of this proteostasis network increases the risk of human diseases associated with protein misfolding and aggregation ${ }^{1}$.

While most proteins adopt a defined three-dimensional structure, several exceptions are known to exist. Notable examples include prions that can adopt multiple, distinct, three-dimensional structures $^{3-5}$, and an ever-increasing number of intrinsically disordered proteins (IDPs), which feature large regions of random coil or lack a defined structure altogether ${ }^{6-8}$. At least in yeast, it is now widely accepted that molecular chaperones play an essential role in prion replication ${ }^{9,10}$ by governing the inheritance and maintenance of yeast prions, and in some cases their elimination by chaperone overexpression $^{11-15}$. However, concrete evidence of an involvement of molecular chaperones in mammalian prion replication, although proposed ${ }^{16}$, is missing, and whether molecular chaperones play a role in the stabilization and/or protection of IDPs remains uncertain.

What is a molecular chaperone? A molecular chaperone can be generally defined as any protein that assists other macromolecules in folding and/or assembling into higher order structures, without it being a component of these final structures ${ }^{17}$. Thus, while their main function inside the cell is to assist in the folding and maturation of unfolded or partially folded macromolecules and to prevent their misfolding and aggregation, it was widely assumed that molecular chaperones involved in de novo protein folding do not recover functional protein once aggregation has occurred. This concept was challenged by the discovery of a novel stress-inducible molecular chaperone known as Hsp104 ${ }^{18}$, which functions as an ATP-dependent protein disaggregase that rescues stress-damaged proteins from a previously aggregated state ${ }^{19,20}$. The discovery of Hsp104 has since expanded our definition of molecular chaperones to include those that promote the forward folding or prevent the aggregation of proteins on one hand, and those that recover functional protein from aggregates on the other hand.

At the molecular level, molecular chaperones come in diverse shapes and sizes, and can be broadly separated into two groups: those that depend on metabolic energy to fuel their chaperone activity, and those that do not ${ }^{21}$. Examples of the former include all ATP-dependent molecular chaperones ${ }^{22}$, while the latter include small heat shock proteins ${ }^{23}$, protein disulfide isomerase ${ }^{24}$, ribosomeassociated chaperones such as trigger factor ${ }^{25}$, and conditionally activated chaperones ${ }^{26}$.
The focus of this review is on ATP-dependent molecular chaperones that harness the energy from ATP binding and/or hydrolysis to assist protein folding and unfolding (i.e., disaggregation). Their cellular expression can be either constitutive in order to perform vital housekeeping functions, or inducible by short exposure to elevated temperatures or other forms of stress that cause protein denaturation. Those that are stress-inducible are also known as heat-shock proteins or HSPs, while those that are constitutively active are termed heat-shock cognates or HSCs. Different members of both groups are classified according to their molecular weight, for example, HSP of 60-kDa (Hsp60), 70-kDa (Hsp70), 90-kDa (Hsp90), and 100-kDa (Hsp100), although many are better known by their common name that is used to designate each chaperone homolog from eubacteria, for example, GroEL (Hsp60), DnaK (Hsp70), HtpG (Hsp90), and ClpB (Hsp100) (Figure 1). All of these aforementioned HSPs bind adenine nucleotide and hydrolyze ATP. Furthermore, another common feature is their cooperation with other proteins, termed co-chaperones, which regulate the ATPase and/or chaperone activity, or reset the functional cycle.

\section{The Hsp60 family}

Hsp60 chaperones are known as chaperonins ${ }^{27}$, and can be divided into two subgroups. Group I chaperonins are sevenfold symmetric and assemble into a barrel-like structure composed of two rings of seven identical subunits ${ }^{28}$. Notable examples include bacterial GroEL and Hsp60 from mitochondria and chloroplasts. Each GroEL subunit consists of an equatorial, intermediate, and apical domain (Figure $1 \mathrm{a})^{29-31}$. ATP binding triggers a conformational rearrangement of the apical domains followed by GroES binding. The latter is a GroEL co-chaperone that assembles into a heptamer ring ${ }^{32}$, and caps one side of the GroEL barrel (the cis ring) ${ }^{33}$ to encapsulate the substrate $^{34}$, and to promote protein folding ${ }^{35}$. The prevailing model suggests that GroEL-ES promotes folding through repetitive binding, encapsulation, and release of the substrate protein ${ }^{28,36}$. Group II chaperonins are homo- or hetero-oligomers forming an eightfold double barrel structure composed of sixteen subunits, and include the eukaryotic chaperonin containing TCP1 complex (CCT), also known as the TCP-1 Ring Complex (TRiC), and the thermosome and Methanococcus maripaludis chaperonin (Mm-Cpn) from Archaea $^{37}$. Unlike Group I chaperonins, group II members do not function together with a GroES-like co-chaperone, but instead contain a built-in lid that undergoes an iris-like motion to promote protein folding ${ }^{38}$.

Much of our current understanding of chaperonin function comes from seminal work on Escherichia coli GroEL. E. coli GroEL is essential since many vital proteins, including metabolic enzymes and components of the transcription-translation machinery, depend on the GroE system for folding ${ }^{39}$. While GroEL's essential housekeeping function is beginning to be understood, an emerging question is the recent appreciation of multiple copies of GroEL in some bacterial genomes ${ }^{40}$, as seen in actinobacteria, which includes Mycobacterium tuberculosis, the causative agent of Tuberculosis (TB). TB accounts for $\sim 2$ million deaths annually and is a major public health problem exacerbated by the emergence and rapid spread of new multidrug-resistant $M$. tuberculosis strains. M. tuberculosis encodes two copies of groEL in its genome ${ }^{40}$. While 
(a)

\section{Hsp60/GroEL (PDB:1AON)}

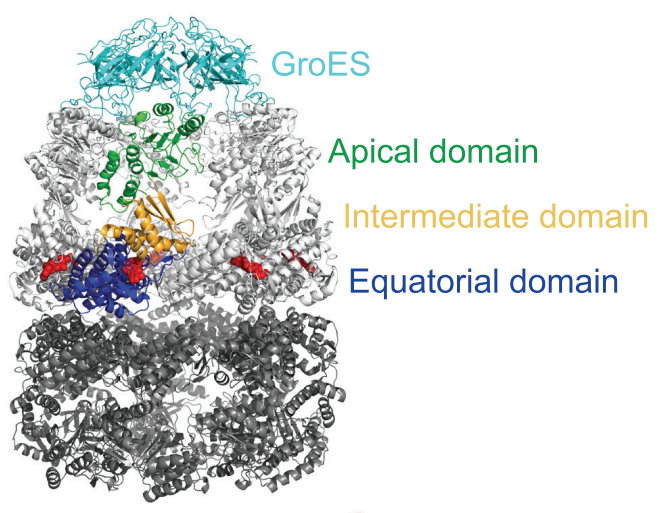

(b)

(c)

Hsp70/DnaK

(PDB:4JNE)

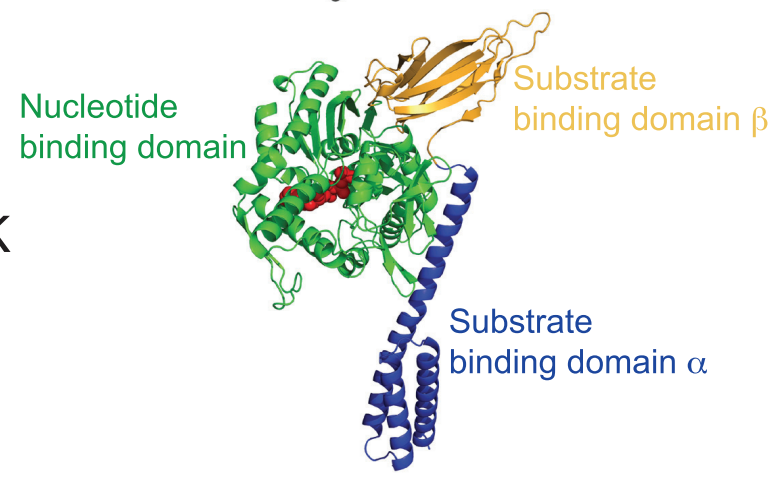

Hsp90/HtpG

(PDB:2CG9)

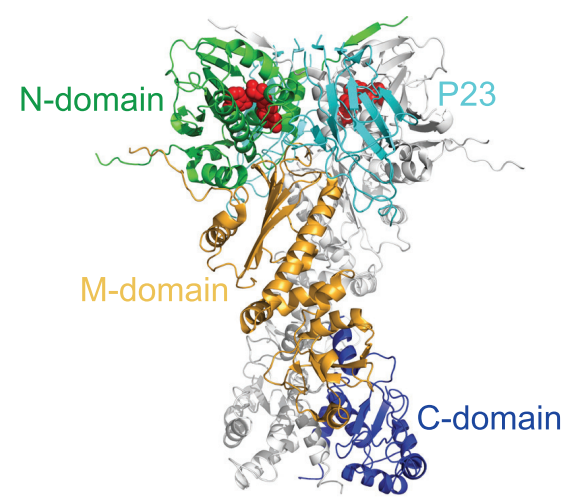

(d)

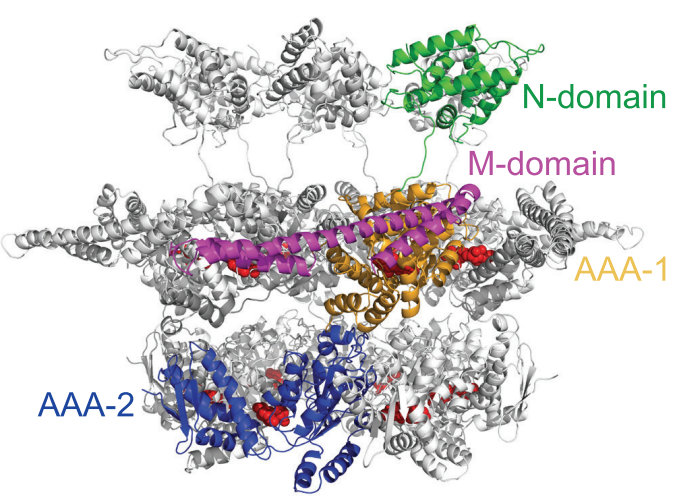

Figure 1. Molecular architecture and domain organization of ATP-dependent molecular chaperones. Protein is shown as ribbon diagram with the bound nucleotide as red CPK model. For each chaperone, the domains of one subunit are shown in different colors in order of green, orange, and blue from N- to C-termini. Bound co-chaperones are colored cyan. (a) Hsp60/GroEL: Architecture and domain organization of the E. coli GroEL tetradecamer bound to ADP with a GroES heptamer capping the GroEL cis ring (PDB: 1AON) ${ }^{33}$. (b) Hsp70/DnaK: Architecture and domain organization of the E. coli DnaK monomer in the ATP-bound state (PDB: 4JNE) ${ }^{54}$. (c) Hsp90/HtpG: Architecture and domain organization of the ATP-bound yeast Hsp90 dimer in the closed-state conformation, and its stabilization by p23/Sba1 (PDB: 2CG9) ${ }^{81}$. (d) Hsp104/ClpB: Architecture and domain organization of a yeast Hsp104 hexamer bound to ATP (PDB: 1QVR; EMD-1631) ${ }^{97,99}$. The Hsp104 $\mathrm{M}$-domain that mediates the species-specific interaction with $\mathrm{Hsp} 70$ is colored in magenta. 
M. tuberculosis GroEL2 is essential for viability, the function of the non-essential GroEL1 paralog remains less clear. The crystal structures of M. tuberculosis GroEL2 and a GroEL1 fragment showed that the apical domains have nearly identical three-dimensional structures $^{41,42}$. While GroEL2 is believed to be the housekeeping chaperonin similar to E. coli GroEL, GroEL1 may function as a specialized chaperonin with a more limited substrate spectrum. Consistent with this notion, it has been proposed that mycobacterial GroEL1 is a dedicated chaperone for biofilm formation ${ }^{43}$, which is presumed to confer the extraordinary starvation survival and resistance of $M$. tuberculosis to known antibiotics ${ }^{44}$.

\section{The Hsp70 family}

Members of the Hsp70 chaperone family are found in all three surviving domains of life $\mathrm{e}^{45}$. At the molecular level, Hsp70 is a two-domain protein consisting of a nucleotide-binding domain connected by a long and flexible hydrophobic linker to the substrate-binding domain that can be subdivided into a $\beta$-sandwich domain and an $\alpha$-helical domain (Figure 1b). Furthermore, cytosolic eukaryotic Hsp70s feature a Glu-Glu-Val-Asp or "EEVD" motif at the extreme $\mathrm{C}$-terminus, which is required for the interaction with Hsp70 co-chaperones that regulate the Hsp70 ATPase activity and its ability to bind substrate ${ }^{46}$. It has been shown that bacterial Hsp70 recognizes diverse polypeptides mostly in an unfolded or partially unfolded form by binding to a four to five residue stretch of hydrophobic amino acids flanked by regions enriched in basic amino $\operatorname{acids}^{47}$, which occur on average every $30-40$ residues in most proteins. Since Hsp70 binding motifs are typically buried within the correctly folded protein, it provides a means to selectively seek out and bind proteins that are in a non-native conformation. However, Hsp70 chaperones rarely, if ever, function on their own and require the assistance of co-chaperones, which include nucleotide exchange factors, such as bacterial GrpE and eukaryotic Hsp110, and the large family of J-domain-containing Hsp40 co-chaperones, which accelerate ATP hydrolysis, serve as substrate targeting factors, and stabilize Hsp70-substrate interaction ${ }^{21}$.

Over the last decade, high-resolution structural information on fulllength Hsp70 chaperones has become available ${ }^{48-54}$, providing new insight into the Hsp70 conformational cycle and its allosteric regulation by nucleotide ${ }^{55}$. Hsp70 function is controlled by nucleotide binding with ATP, promoting an open-conformation with low substrate-binding affinity, and ADP, promoting a closed-conformation required for tight binding of substrates ${ }^{21}$.

In addition to Hsp70's known role in protein folding, Hsp70 also has other non-chaperone functions. For instance, it was recently shown that Hsp70 functions as an activator of the ring-forming Hsp104 protein disaggregase and is required to unleash the potent protein disaggregating activity ${ }^{56,57}$. While no Hsp104 homolog is known to exist in metazoans, the discovery of a mammalian protein disaggregase, composed of Hsp70, Hsp110, and Hsp40, is exciting and supports functional conservation of a protein disaggregating activity in animal cells ${ }^{58-61}$. However, despite its nomenclature, Hsp110 is not an Hsp100 homolog, but instead belongs to an Hsp70 subfamily that is activated by nucleotide ${ }^{62}$, shares structural ${ }^{49,63,64}$ and perhaps functional conservation with $\mathrm{Hsp} 70^{65}$, and functions as an Hsp70 nucleotide exchange factor ${ }^{66,67}$.

\section{The Hsp90 family}

Hsp90 belongs to a conserved group of ATP-dependent molecular chaperones ${ }^{68-70}$ which, together with Hsp70 and a cohort of co-chaperones, facilitates the late-stage folding and maturation of proteins $^{71,72}$. Since Hsp90 substrates are mostly substantially folded proteins, they are known as "client proteins" ${ }^{8}$ to distinguish them from other chaperone substrates that lack a defined structure. More than 400 different clients are known to depend on Hsp90 for folding or maturation, and include protein kinases, transcription factors, and E3 ubiquitin ligases ${ }^{73}$. The large number of signaling and tumor promoting proteins amongst Hsp90 clients has made Hsp90 a promising drug target ${ }^{74}$.

Apart from Hsp90 chaperones in the eukaryotic cytosol, Hsp90 homologs are found in bacteria (HtpG) and eukaryotic organelles, including the endoplasmic reticulum (Grp94), mitochondrion (TRAP1), and chloroplast ${ }^{75}$. Interestingly, Hsp90-like domains with chaperone activity have also been found in Sacsin, a 521-kDa protein associated with an autosomal recessive form of spastic $\operatorname{ataxia}^{76,77}$. However, an Hsp90 homolog has not been found in Archaea.

Hsp90 chaperones share a similar domain structure consisting of an N-terminal (N-) nucleotide-binding domain, a middle (M-) domain, and a C-terminal (C-) dimerization domain (Figure 1c). The $\mathrm{N}$-domain is connected to the M-domain via a flexible linker that is often highly charged and, in human Hsp90, is over 60 residues in length. While important to cytosolic eukaryotic Hsp90 function $^{78-80}$, the charged-linker is not universally conserved and is essentially absent in both bacterial and mitochondrial Hsp90s. Crystal structures are now available for full-length members of all Hsp90 subfamilies mostly with bound nucleotide ${ }^{81-84}$, including the recent structure of an asymmetric TRAP1 dimer in the ATP-bound state $^{84}$. The latter lends supports for a sequential ATP hydrolysis mechanism ${ }^{85,86}$, although asymmetric binding of nucleotide was not observed ${ }^{84}$. Consistent with the prevailing notion, the available structures confirmed that all Hsp90 chaperones form homodimers with the $\mathrm{N}$-domain mediating nucleotide binding. Strikingly, however, apo Hsp90 forms a wide-open, V-shaped dimer with the N-domains separated by over $100 \AA^{82}$, while Hsp90 in the ATPbound state adopts an intertwined, $\mathrm{N}$-terminally closed dimer ${ }^{81,84}$. Since the N-domains are too far apart in the open-state to signal the nucleotide status between neighboring subunits, how ATP-binding induces the closed-state conformation remains an open question. One model suggests that Hsp90 chaperones sample different threedimensional conformations with different adenine nucleotides stabilizing distinct Hsp90 dimer conformations ${ }^{87-89}$. While not mutually exclusive, the crystal structures of intact Grp94, which were determined in the ATP- and ADP-bound state, revealed a very similar Hsp90 dimer conformation irrespective of the nature of the bound nucleotide ${ }^{83}$. Hence, further in vitro and in vivo studies are needed to address the exact roles of ATP and ADP for Hsp90 chaperone function.

\section{The Hsp100 family}

Members of the Hsp100 family were first discovered as the protein-activated ATPase components of the protease Ti from E. coli $^{90,91}$, now better known as the ClpAP protease. Members of 
the Hsp100/Clp family belong to the large superfamily of ATPases Associated with diverse cellular Activities (AAA+) ${ }^{92,93}$. Hsp100/Clp members form a hexameric ring structure and function as the proteinunfolding component of chambered proteases ${ }^{94,95}$. The discovery of yeast Hsp104 that facilitates protein disaggregation ${ }^{19}$, as opposed to targeting proteins for degradation, established Hsp104 as the founding member of a new family of ATP-dependent molecular chaperones. In addition to yeast Hsp104, Hsp104 homologs were found subsequently in bacteria (ClpB), plants (Hsp101), and most recently in Dictyostelium discoideum (Hsp101) ${ }^{96}$.

Like all Hsp100/Clp proteins, Hsp104 forms an oligomer, with the homohexamer being the functionally active form ${ }^{97-100}$. Hsp104 features two canonical Walker-type ATP-binding domains, known as AAA domains, in addition to several other structural elements that define members of the AAA+ superfamily and include the so-called arginine-finger and the sensor 1 and 2 motifs $^{101-106}$. While the Hsp104 hexamer is stabilized by nucleotide and is an active ATPase in vitro ${ }^{107,108}$, it requires the cooperation of the cognate Hsp70 chaperone system, consisting of Hsp70 and Hsp40 in yeast ${ }^{20}$ and DnaK, DnaJ, and GrpE in eubacteria ${ }^{109-111}$, to recover functional protein from aggregates.

At the molecular level, Hsp104 consists of an N-terminal domain, and two tandem AAA+ domains, termed AAA-1 and AAA-2 (Figure 1d) ${ }^{97,103}$. The AAA-1 domain features an 85- $\AA$ long coiledcoil insertion, known as the M-domain, which is located on the outside of the hexamer ${ }^{99,100,112}$ and distinguishes Hsp104 members from other Hsp100/Clp ATPases. The M-domain is essential for protein disaggregation by mediating the interaction between Hsp104 and Hsp70 $0^{113-115}$, and may function as a molecular toggle to allosterically control the ATPase and mechanical activities of the Hsp104 motor $^{116}$.

How Hsp104 facilitates protein disaggregation has been revealed by the combined efforts of several groups ${ }^{117}$. It is now widely accepted that, inside the cell, the Hsp70 system targets the Hsp104 motor to both amorphous and ordered aggregates ${ }^{15,118}$, from which Hsp104 extracts polypeptides using an ATP-driven power stroke involving pore loops present in the AAA-1 and AAA-2 domains ${ }^{119}$, and threading the polypeptide through the central channel of the Hsp104 hexamer ${ }^{120,121}$.

While we are beginning to understand the function of the M- and AAA domains, the role of the $\mathrm{N}$-domain is less clear. It was shown that the $\mathrm{N}$-domain is dispensable for Hsp104 function in vitro and in vivo ${ }^{15,103,122-125}$. However, others found that the $\mathrm{N}$-domain is essential for bacterial Hsp104 ${ }^{126,127}$ and mediates substrate interaction $^{126,128-131}$. Consistently, the N-domain of yeast Hsp104 enhances protein disaggregation in vitro ${ }^{114}$, mediates prion interaction in yeast ${ }^{132}$, and is essential for yeast prion dissolution ${ }^{112}$ and curing by Hsp104 overexpression ${ }^{124}$.
In addition to Hsp104's role in yeast stress responses and yeast prion replication, new roles are emerging, including the asymmetric distribution of oxidative damaged proteins ${ }^{133,134}$, facilitating the sorting of tail-anchored proteins to the endoplasmic reticulum membrane $e^{135}$, and septin folding and assembly ${ }^{136}$. Hence, future studies will provide a more complete picture as to the extent of Hsp104's cellular function.

\section{Future perspectives}

It is now widely appreciated that molecular chaperones are intimately linked to proteostasis maintenance and are essential to cell and organismal health. Perturbation of the proteostasis network, for instance by "chaperone overload"137 or polyglutamine expansion ${ }^{138}$, invariably disrupts the balance of the protein folding landscape triggering protein misfolding and the formation of aggregates that are hallmarks of neurodegenerative diseases, prion-mediated infections, and amyloidosis. At the same time, a controlled perturbation of the functional interaction between molecular chaperones and proteases could provide new avenues for therapeutic intervention. This could be achieved by using small molecule compounds, or by RNA interference, or restoring the proteostasis network in disease states, for instance with chemical chaperones or by induced chaperone expression ${ }^{139,140}$.

\section{Author contributions}

Wilson Jeng, Sukyeong Lee, Nuri Sung, Jungsoon Lee, and Francis T.F. Tsai conceived the study. Wilson Jeng, Sukyeong Lee, and Francis T.F. Tsai prepared the first draft of the manuscript. All authors were involved in the revision of the draft manuscript and have agreed to the final content.

\section{Competing interests}

The authors declare there were no competing interests.

\section{Grant information}

Research in the Francis T.F. Tsai and Sukyeong Lee laboratory is supported by grants from the National Institutes of Health (R01-GM111084 and R01-GM104980) and the Robert A. Welch Foundation (Q-1530).

I confirm that the funders had no role in study design, data collection and analysis, decision to publish, or preparation of the manuscript.

\section{Acknowledgements}

We sincerely apologize to all those colleagues whose important work was not cited in this review. We also wish to thank all present and past members of the Francis T.F. Tsai and Sukyeong Lee laboratory for their intellectual contributions towards providing a better mechanistic understanding of molecular chaperone structure and function. 
1. Brandvold KR, Morimoto RI: The Chemical Biology of Molecular Chaperones-Implications for Modulation of Proteostasis. J Mol Biol. 2015; 427(18): 2931-47. PubMed Abstract | Publisher Full Text

2. Hipp MS, Park SH, Hartl FU: Proteostasis impairment in protein-misfolding and -aggregation diseases. Trends Cell Biol. 2014; 24(9): 506-14.

PubMed Abstract | Publisher Full Tex

3. Baxa U, Cassese T, Kajava AV, et al:: Structure, function, and amyloidogenesis of fungal prions: filament polymorphism and prion variants. Adv Protein Chem. 2006; 73: 125-80

PubMed Abstract | Publisher Full Text

4. Toyama BH, Weissman JS: Amyloid structure: conformational diversity and consequences. Annu Rev Biochem. 2011; 80: 557-85.

PubMed Abstract | Publisher Full Text | Free Full Text

5. Eisenberg D, Jucker M: The amyloid state of proteins in human diseases. Cell. 2012: 148(6): 1188-203.

PubMed Abstract | Publisher Full Text | Free Full Text

6. Varadi M, Kosol S, Lebrun P, et al:: pE-DB: a database of structural ensembles of intrinsically disordered and of unfolded proteins. Nucleic Acids Res. 2014; 42(Database issue): D326-35.

PubMed Abstract | Publisher Full Text | Free Full Text

7. Oldfield CJ, Dunker AK: Intrinsically disordered proteins and intrinsically disordered protein regions. Annu Rev Biochem. 2014; 83: 553-84. PubMed Abstract | Publisher Full Text

8. Arai M, Sugase $\mathrm{K}$, Dyson $\mathrm{HJ}$, et al.: Conformational propensities of intrinsically disordered proteins influence the mechanism of binding and folding. Proc Natl Acad Sci U S A. 2015; 112(31): 9614-9.

PubMed Abstract | Publisher Full Text | Free Full Text

9. Wickner RB, Shewmaker FP, Bateman DA, et al:: Yeast prions: structure, biology, and prion-handling systems. Microbiol Mol Biol Rev. 2015; 79(1): 1-17. PubMed Abstract | Publisher Full Text | Free Full Text

10. Masison DC, Reidy M: Yeast prions are useful for studying protein chaperones and protein quality control. Prion. 2015; 9(3): 174-83. PubMed Abstract | Publisher Full Text

11. Chernoff YO, Lindquist SL, Ono B, et al:: Role of the chaperone protein Hsp104 in propagation of the yeast prion-like factor [psi+]. Science. 1995; 268(5212): $880-4$.

PubMed Abstract | Publisher Full Text

12. Moriyama $\mathrm{H}$, Edskes $\mathrm{HK}$, Wickner RB: [URE3] prion propagation in Saccharomyces cerevisiae: requirement for chaperone Hsp104 and curing by overexpressed chaperone Ydj1p. Mol Cell Biol. 2000; 20(23): 8916-22. PubMed Abstract | Free Full Text

13. Shorter J, Lindquist S: Hsp104, Hsp70 and Hsp40 interplay regulates formation, growth and elimination of Sup35 prions. EMBO J. 2008; 27(20): 2712-24. PubMed Abstract | Publisher Full Text | Free Full Text

14. Higurashi T, Hines JK, Sahi C, et al:: Specificity of the J-protein Sis1 in the propagation of 3 yeast prions. Proc Natl Acad Sci U S A. 2008; 105(43) 16596-601.

PubMed Abstract | Publisher Full Text | Free Full Text

15. Tipton KA, Verges KJ, Weissman JS: In vivo monitoring of the prion replication cycle reveals a critical role for Sis1 in delivering substrates to Hsp104. Mol Cell. 2008; 32(4): 584-91.

PubMed Abstract | Publisher Full Text | Free Full Text

16. Telling GC, Scott M, Mastrianni J, et al.: Prion propagation in mice expressing human and chimeric PrP transgenes implicates the interaction of cellular PrP with another protein. Cell. 1995; 83(1): 79-90.

PubMed Abstract | Publisher Full Text

17. Quinlan RA, Ellis RJ: Chaperones: needed for both the good times and the bad times. Philos Trans R Soc Lond B Biol Sci. 2013; 368(1617): 20130091. PubMed Abstract | Publisher Full Text | Free Full Text

18. Sanchez Y, Lindquist SL: HSP104 required for induced thermotolerance. Science. 1990; 248(4959): 1112-5.

PubMed Abstract | Publisher Full Text

19. Parsell DA, Kowal AS, Singer MA, et al.: Protein disaggregation mediated by heat-shock protein Hsp104. Nature. 1994; 372(6505): 475-8. PubMed Abstract | Publisher Full Text

20. Glover JR, Lindquist S: Hsp104, Hsp70, and Hsp40: a novel chaperone system that rescues previously aggregated proteins. Cell. 1998; 94(1): 73-82. PubMed Abstract | Publisher Full Text

21. Hartl FU, Bracher A, Hayer-Hartl M: Molecular chaperones in protein folding and proteostasis. Nature 2011; 475(7356): 324-32. PubMed Abstract | Publisher Full Text

22. Saibil $\mathrm{H}$ : Chaperone machines for protein folding, unfolding and disaggregation. Nat Rev Mol Cell Biol. 2013; 14(10): 630-42. PubMed Abstract | Publisher Full Text | Free Full Text

23. Haslbeck M, Vierling E: A first line of stress defense: small heat shock proteins and their function in protein homeostasis. J Mol Biol. 2015; 427(7): 1537-48. PubMed Abstract | Publisher Full Text | Free Full Text

24. Wang $L$, Wang $X$, Wang $C C$, et al:: Protein disulfide-isomerase, a folding catalyst and a redox-regulated chaperone. Free Radic Biol Med. 2015; 83
305-13.

PubMed Abstract | Publisher Full Text

25. Preissler S, Deuerling E: Ribosome-associated chaperones as key players in proteostasis. Trends Biochem Sci. 2012; 37(7): 274-83.

PubMed Abstract | Publisher Full Text

26. Bardwell JC, Jakob U: Conditional disorder in chaperone action. Trends Biochem Sci. 2012; 37(12): 517-25.

PubMed Abstract | Publisher Full Text | Free Full Text

27. Hemmingsen SM, Woolford C, van der Vies SM, et al:: Homologous plant and bacterial proteins chaperone oligomeric protein assembly. Nature. 1988; 333(6171): 330-4

PubMed Abstract | Publisher Full Text

28. Hayer-Hartl M, Bracher A, Hartl FU: The GroEL-GroES Chaperonin Machine: A Nano-Cage for Protein Folding. Trends Biochem Sci. 2015; pii: S09680004(15)00140-1.

PubMed Abstract | Publisher Full Text

29. Braig K, Otwinowski Z, Hegde R, et al:: The crystal structure of the bacterial chaperonin GroEL at $2.8 \AA$. Nature. 1994; 371(6498): 578-86. PublMed Abstract | Publisher Full Text

30. Fukami TA, Yohda M, Taguchi $\mathrm{H}$, et al.: Crystal structure of chaperonin-60 from Paracoccus denitrificans. J Mol Biol. 2001; 312(3): 501-9. PubMed Abstract | Publisher Full Text

31. Wang J, Boisvert DC: Structural basis for GroEL-assisted protein folding from the crystal structure of (GroEL-KMgATP) ${ }_{14}$ at $2.0 \AA$ resolution. $J$ Mol Biol. 2003; 327(4): 843-55.

PubMed Abstract | Publisher Full Text

32. Hunt JF, Weaver AJ, Landry SJ, et al.: The crystal structure of the GroES co-chaperonin at 2.8 Å resolution. Nature. 1996; 379(6560): 37-45. PubMed Abstract | Publisher Full Text

33. $\mathrm{Xu} \mathrm{Z,} \mathrm{Horwich} \mathrm{AL,} \mathrm{Sigler} \mathrm{PB:} \mathrm{The} \mathrm{crystal} \mathrm{structure} \mathrm{of} \mathrm{the} \mathrm{asymmetric} \mathrm{GroEL-}$ GroES-(ADP) ${ }_{7}$ chaperonin complex. Nature. 1997; 388(6644): 741-50. PubMed Abstract | Publisher Full Text

34. Chen DH, Madan D, Weaver J, et al:: Visualizing GroEL/ES in the act of encapsulating a folding protein. Cell. 2013; 153(6): 1354-65. PubMed Abstract | Publisher Full Text | Free Full Text

35. Sigler PB, Xu Z, Rye HS, et al:: Structure and function in GroEL-mediated protein folding. Annu Rev Biochem. 1998; 67: 581-608. PubMed Abstract | Publisher Full Text

36. Horwich AL, Fenton WA: Chaperonin-mediated protein folding: using a centra cavity to kinetically assist polypeptide chain folding. Q Rev Biophys. 2009; 42(2): 83-116.

PubMed Abstract | Publisher Full Text

37. Lopez T, Dalton K, Frydman J: The Mechanism and Function of Group II Chaperonins. J Mol Biol. 2015; 427(18): 2919-30. PubMed Abstract | Publisher Full Text

38. Booth CR, Meyer AS, Cong $\mathrm{Y}$, et al:: Mechanism of lid closure in the eukaryotic chaperonin TRiC/CCT. Nat Struct Mol Biol. 2008; 15(7): 746-53. PubMed Abstract | Publisher Full Text | Free Full Text

39. Houry WA, Frishman D, Eckerskorn $\mathrm{C}$, et al:: Identification of in vivo substrates of the chaperonin GroEL. Nature. 1999; 402(6758): 147-54. PubMed Abstract | Publisher Full Text

40. Lund PA: Multiple chaperonins in bacteria--why so many? FEMS Microbiol Rev 2009; 33(4): 785-800.

PubMed Abstract | Publisher Full Text

41. Qamra R, Mande SC: Crystal structure of the 65-kilodalton heat shock protein chaperonin 60.2, of Mycobacterium tuberculosis. J Bacteriol. 2004; 186(23): 8105-13.

PubMed Abstract | Publisher Full Text | Free Full Text

42. Sielaff $B$, Lee KS, Tsai FT: Structural and functional conservation of Mycobacterium tuberculosis GroEL paralogs suggests that GroEL1 Is a chaperonin. J Mol Biol. 2011; 405(3): 831-9.

PubMed Abstract | Publisher Full Text | Free Full Text

43. F Ojha A, Anand M, Bhatt A, et al:: GroEL1: a dedicated chaperone involved in mycolic acid biosynthesis during biofilm formation in mycobacteria. Cell. 2005; 123(5): 861-73.

PubMed Abstract | Publisher Full Text | F1000 Recommendation

44. Islam MS, Richards JP, Ojha AK: Targeting drug tolerance in mycobacteria: a perspective from mycobacterial biofilms. Expert Rev Anti Infect Ther. 2012; 10(9): 1055-66.

PubMed Abstract | Publisher Full Text | Free Full Text

45. Powers ET, Balch WE: Diversity in the origins of proteostasis networks--a driver for protein function in evolution. Nat Rev Mol Cell Biol. 2013; 14(4): 237-48.

PubMed Abstract | Publisher Full Text | Free Full Text

46. Freeman $\mathrm{BC}$, Myers MP, Schumacher $\mathrm{R}$, et al.: Identification of a regulatory motif in Hsp70 that affects ATPase activity, substrate binding and interaction with HDJ-1. EMBO J. 1995; 14(10): 2281-92.

PubMed Abstract | Free Full Text

47. Rüdiger S, Germeroth L, Schneider-Mergener J, et al:: Substrate specificity of the 
DnaK chaperone determined by screening cellulose-bound peptide libraries. EMBO J. 1997; 16(7): 1501-7.

PubMed Abstract | Publisher Full Text | Free Full Text

48. F Jiang J, Prasad K, Lafer EM, et al.: Structural basis of interdomain communication in the Hsc70 chaperone. Mol Cell. 2005; 20(4): 513-24. PubMed Abstract | Publisher Full Text | Free Full Text | F1000 Recommendation

49. F Liu Q, Hendrickson WA: Insights into Hsp70 chaperone activity from a crystal structure of the yeast Hsp110 Sse1. Cell. 2007; 131(1): 106-20. PubMed Abstract | Publisher Full Text | Free Full Text | F1000 Recommendation

50. Chang YW, Sun YJ, Wang C, et al.: Crystal structures of the 70-kDa heat shock proteins in domain disjoining conformation. J Biol Chem. 2008; 283(22): 15502-11

PubMed Abstract | Publisher Full Text | Free Full Text

51. F Bertelsen EB, Chang L, Gestwicki JE, et al.: Solution conformation of wildtype E. coli Hsp70 (DnaK) chaperone complexed with ADP and substrate. Proc Natl Acad Sci U S A. 2009; 106(21): 8471-6.

PubMed Abstract | Publisher Full Text | Free Full Text | F1000 Recommendation

52. F Zhuravleva A, Clerico EM, Gierasch LM: An interdomain energetic tug-of-war creates the allosterically active state in Hsp70 molecular chaperones. Cell. 2012; 151(6): 1296-307.

PubMed Abstract | Publisher Full Text | Free Full Text | F1000 Recommendation

53. F Kityk R, Kopp J, Sinning I, et al.: Structure and dynamics of the ATP-bound open conformation of Hsp70 chaperones. Mol Cell. 2012; 48(6): 863-74. PubMed Abstract | Publisher Full Text | F1000 Recommendation

54. Qi R, Sarbeng EB, Liu Q, et al.: Allosteric opening of the polypeptide-binding site when an Hsp70 binds ATP. Nat Struct Mol Biol. 2013; 20(7): 900-7. PubMed Abstract | Publisher Full Text | Free Full Text

55. Mayer MP: Hsp70 chaperone dynamics and molecular mechanism. Trends Biochem Sci. 2013; 38(10): 507-14.

PubMed Abstract | Publisher Full Text

56. Seyffer $F$, Kummer E, Oguchi $Y$, et al:: Hsp70 proteins bind Hsp100 regulatory $M$ domains to activate AAA+ disaggregase at aggregate surfaces. Nat Struct Mol Biol. 2012; 19(12): 1347-55. PubMed Abstract | Publisher Full Tex

57. Lee J, Kim JH, Biter AB, et al.: Heat shock protein (Hsp) 70 is an activator of the Hsp104 motor. Proc Natl Acad Sci U S A. 2013; 110(21): 8513-8. PubMed Abstract | Publisher Full Text | Free Full Text

58. Shorter J: The mammalian disaggregase machinery: Hsp110 synergizes with Hsp70 and $\mathrm{Hsp} 40$ to catalyze protein disaggregation and reactivation in a cell-free system. PLoS One. 2011; 6(10): e26319. PubMed Abstract | Publisher Full Text | Free Full Text

59. Rampelt $\mathrm{H}$, Kirstein-Miles J, Nillegoda NB, et al.: Metazoan Hsp70 machines use Hsp110 to power protein disaggregation. EMBO J. 2012; 31(21): 4221-35. PubMed Abstract | Publisher Full Text | Free Full Text

60. Song $\mathrm{Y}, \mathrm{Nagy} \mathrm{M}, \mathrm{Ni} \mathrm{W}$, et al.: Molecular chaperone Hsp110 rescues a vesicle transport defect produced by an ALS-associated mutant SOD1 protein in squid axoplasm. Proc Natl Acad Sci U S A. 2013; 110(14): 5428-33. PubMed Abstract | Publisher Full Text | Free Full Text

61. Nillegoda NB, Kirstein J, Szlachcic A, et al.: Crucial HSP70 co-chaperone complex unlocks metazoan protein disaggregation. Nature. 2015; 524(7564): $247-51$

PubMed Abstract | Publisher Full Text

62. Andréasson $\mathrm{C}$, Fiaux J, Rampelt $\mathrm{H}$, et al:: Hsp110 is a nucleotide-activated exchange factor for Hsp70. J Biol Chem. 2008; 283(14): 8877-84. PubMed Abstract | Publisher Full Text

63. F Polier S, Dragovic Z, Hartl FU, et al:: Structural basis for the cooperation of Hsp70 and Hsp110 chaperones in protein folding. Cell. 2008; 133(6): 1068-79. PubMed Abstract | Publisher Full Text | F1000 Recommendation

64. F Schuermann JP, Jiang J, Cuellar J, et al.: Structure of the Hsp110:Hsc70 nucleotide exchange machine. Mol Cell. 2008; 31(2): 232-43. PubMed Abstract | Publisher Full Text | Free Full Text | F1000 Recommendation

65. Mattoo RU, Sharma SK, Priya S, et al:: Hsp110 is a bona fide chaperone using ATP to unfold stable misfolded polypeptides and reciprocally collaborate with Hsp70 to solubilize protein aggregates. J Biol Chem. 2013; 288(29): 21399-411. PubMed Abstract | Publisher Full Text | Free Full Text

66. Raviol H, Sadlish $\mathrm{H}$, Rodriguez $\mathrm{F}$, et al:: Chaperone network in the yeast cytosol: Hsp110 is revealed as an Hsp70 nucleotide exchange factor. EMBO J. 2006; 25(11): 2510-8.

PubMed Abstract | Publisher Full Text | Free Full Text

67. Abrams JL, Verghese J, Gibney PA, et al:: Hierarchical functional specificity of cytosolic heat shock protein 70 (Hsp70) nucleotide exchange factors in yeast. J Biol Chem. 2014; 289(19): 13155-67.

PubMed Abstract | Publisher Full Text | Free Full Text

68. Pearl LH, Prodromou C: Structure and mechanism of the Hsp90 molecular chaperone machinery. Annu Rev Biochem. 2006; 75: 271-94.

PubMed Abstract | Publisher Full Text

69. Krukenberg KA, Street TO, Lavery LA, et al.: Conformational dynamics of the molecular chaperone Hsp90. Q Rev Biophys. 2011; 44(2): 229-55. PubMed Abstract | Publisher Full Text

70. Mayer MP, Le Breton L: Hsp90: breaking the symmetry. Mol Cell. 2015; 58(1): $8-20$

PubMed Abstract | Publisher Full Text
71. Pratt WB, Toft DO: Regulation of signaling protein function and trafficking by the hsp90/hsp70-based chaperone machinery. Exp Biol Med (Maywood). 2003 228(2): 111-33.

PubMed Abstract

72. Li J, Buchner J: Structure, function and regulation of the Hsp90 machinery. Biomed J. 2013; 36(3): 106-17.

PubMed Abstract | Publisher Full Text

73. F Taipale M, Krykbaeva I, Koeva M, et al:: Quantitative analysis of HSP90client interactions reveals principles of substrate recognition. Cell. 2012; 150(5): 987-1001.

PubMed Abstract | Publisher Full Text | Free Full Text | F1000 Recommendation

74. Neckers L, Workman P: Hsp90 molecular chaperone inhibitors: are we there yet? Clin Cancer Res. 2012; 18(1): 64-76.

PubMed Abstract | Publisher Full Text | Free Full Text

75. Johnson JL: Evolution and function of diverse Hsp90 homologs and cochaperone proteins. Biochim Biophys Acta. 2012; 1823(3): 607-13. PubMed Abstract | Publisher Full Text

76. Anderson JF, Siller E, Barral JM: The sacsin repeating region (SRR): a nove Hsp90-related supra-domain associated with neurodegeneration. $J \mathrm{Mol} B \mathrm{BiO}$. 2010; 400(4): 665-74.

PubMed Abstract | Publisher Full Text

77. Anderson JF, Siller E, Barral JM: The neurodegenerative-disease-related protein sacsin is a molecular chaperone. $J$ Mol Biol. 2011; 411(4): 870-80.

PubMed Abstract | Publisher Full Text

78. Tsutsumi S, Mollapour M, Graf C, et al.: Hsp90 charged-linker truncation reverses the functional consequences of weakened hydrophobic contacts in the N domain. Nat Struct Mol Biol. 2009; 16(11): 1141-7.

PubMed Abstract | Publisher Full Text

79. F Tsutsumi S, Mollapour M, Prodromou C, et al:: Charged linker sequence modulates eukaryotic heat shock protein 90 (Hsp90) chaperone activity. Proc Natl Acad Sci U S A. 2012; 109(8): 2937-42.

PubMed Abstract | Publisher Full Text | Free Full Text | F1000 Recommendation

80. Jahn M, Rehn A, Pelz B, et al.: The charged linker of the molecular chaperone Hsp90 modulates domain contacts and biological function. Proc Natl Acad Sci U S A. 2014; 111(50): 17881-6.

PubMed Abstract | Publisher Full Text | Free Full Text

81. F Ali MM, Roe SM, Vaughan CK, et al.: Crystal structure of an Hsp90nucleotide-p23/Sba1 closed chaperone complex. Nature. 2006; 440(7087): $1013-7$.

PubMed Abstract | Publisher Full Text | F1000 Recommendation

82. F Shiau AK, Harris SF, Southworth DR, et al.: Structural Analysis of $E$. coli hsp90 reveals dramatic nucleotide-dependent conformational rearrangements. Cell. 2006; 127(2): 329-40.

PubMed Abstract | Publisher Full Text | F1000 Recommendation

83. Dollins DE, Warren JJ, Immormino RM, et al:: Structures of GRP94-nucleotide complexes reveal mechanistic differences between the hsp90 chaperones. $\mathrm{Mo}$ Cell. 2007; 28(1): 41-56.

PubMed Abstract | Publisher Full Text | Free Full Text

84. F Lavery LA, Partridge JR, Ramelot TA, et al:: Structural asymmetry in the closed state of mitochondrial Hsp90 (TRAP1) supports a two-step ATP hydrolysis mechanism. Mol Cell. 2014; 53(2): 330-43.

PubMed Abstract | Publisher Full Text | Free Full Text | F1000 Recommendation

85. Richter $\mathrm{K}$, Muschler P, Hainzl O, et al:: Coordinated ATP hydrolysis by the Hsp90 dimer. J Biol Chem. 2001; 276(36): 33689-96.

PubMed Abstract | Publisher Full Text

86. Mishra $\mathrm{P}$, Bolon DN: Designed Hsp90 heterodimers reveal an asymmetric ATPase-driven mechanism in vivo. Mol Cell. 2014; 53(2): 344-50. PubMed Abstract | Publisher Full Text | Free Full Text

87. Southworth DR, Agard DA: Species-dependent ensembles of conserved conformational states define the Hsp90 chaperone ATPase cycle. Mol Cell. 2008; 32(5): 631-40.

PubMed Abstract | Publisher Full Text | Free Full Text

88. F Krukenberg KA, Förster F, Rice LM, et al.: Multiple conformations of E. coli Hsp90 in solution: insights into the conformational dynamics of Hsp90. Structure. 2008; 16(5): 755-65.

PubMed Abstract | Publisher Full Text | Free Full Text | F1000 Recommendation

89. Partridge JR, Lavery LA, Elnatan D, et al:: A novel N-terminal extension in mitochondrial TRAP1 serves as a thermal regulator of chaperone activity. eLife. 2014; 3: e03487.

PubMed Abstract | Publisher Full Text | Free Full Text

90. Hwang BJ, Woo KM, Goldberg AL, et al:: Protease Ti, a new ATP-dependent protease in Escherichia coli, contains protein-activated ATPase and proteolytic functions in distinct subunits. J Biol Chem. 1988; 263(18): 8727-34. PubMed Abstract

91. Katayama Y, Gottesman S, Pumphrey J, et al.: The two-component, ATP dependent Clp protease of Escherichia coli. Purification, cloning, and mutational analysis of the ATP-binding component. J Biol Chem. 1988; 263(29): 15226-36.

PubMed Abstract

92. Beyer A: Sequence analysis of the AAA protein family. Protein Sci. 1997; 6(10): 2043-58.

PubMed Abstract | Publisher Full Text | Free Full Tex 
93. Neuwald AF, Aravind L, Spouge JL, et al:: AAA $^{+}$: A class of chaperone-like ATPases associated with the assembly, operation, and disassembly of protein complexes. Genome Res. 1999; 9(1): 27-43.

PubMed Abstract

94. Sauer RT, Baker TA: AAA+ proteases: ATP-fueled machines of protein destruction. Annu Rev Biochem. 2011; 80: 587-612. PubMed Abstract | Publisher Full Text

95. Alexopoulos JA, Guarné A, Ortega J: ClpP: a structurally dynamic protease regulated by AAA+ proteins. J Struct Biol. 2012; 179(2): 202-10. PubMed Abstract | Publisher Full Text

96. F Malinovska L, Palm S, Gibson K, et al:: Dictyostelium discoideum has a highly $\mathrm{Q} / \mathrm{N}$-rich proteome and shows an unusual resilience to protein aggregation. Proc Natl Acad Sci U S A. 2015; 112(20): E2620-9. PubMed Abstract | Publisher Full Text | Free Full Text | F1000 Recommendation

97. Lee S, Sowa ME, Watanabe YH, et al:: The structure of ClpB: a molecula chaperone that rescues proteins from an aggregated state. Cell. 2003; 115(2): $229-40$

PubMed Abstract | Publisher Full Text

98. Lee S, Choi J, Tsai FT: Visualizing the ATPase cycle in a protein disaggregating machine: structural basis for substrate binding by ClpB. Mol Cell. 2007; 25(2): 261-71.

PubMed Abstract | Publisher Full Text | Free Full Text

99. Lee S, Sielaff B, Lee J, et al.: CryoEM structure of Hsp104 and its mechanistic implication for protein disaggregation. Proc Natl Acad Sci U S A. 2010; 107(18): 8135-40.

PubMed Abstract | Publisher Full Text | Free Full Text

100. Carroni M, Kummer E, Oguchi $\mathrm{Y}$, et al:: Head-to-tail interactions of the coiledcoil domains regulate ClpB activity and cooperation with Hsp70 in protein disaggregation. eLife. 2014; 3: e02481.

PubMed Abstract | Publisher Full Text | Free Full Text

101. Hattendorf DA, Lindquist SL: Cooperative kinetics of both Hsp104 ATPase domains and interdomain communication revealed by AAA sensor-1 mutants. EMBO J. 2002; 21(1-2): 12-21.

PubMed Abstract | Publisher Full Text | Free Full Text

102. Hattendorf DA, Lindquist SL: Analysis of the AAA sensor-2 motif in the C-terminal ATPase domain of Hsp104 with a site-specific fluorescent probe of nucleotide binding. Proc Natl Acad Sci U S A. 2002; 99(5): 2732-7. PubMed Abstract | Publisher Full Text | Free Full Text

103. Mogk A, Schlieker C, Strub C, et al:: Roles of individual domains and conserved motifs of the AAA+ chaperone ClpB in oligomerization, ATP hydrolysis, and chaperone activity. J Biol Chem. 2003; 278(20): 17615-24. PubMed Abstract | Publisher Full Text

104. Yamasaki T, Nakazaki Y, Yoshida M, et al.: Roles of conserved arginines in ATPbinding domains of AAA+ chaperone ClpB from Thermus thermophilus. FEBS J. 2011; 278(13): 2395-403.

PubMed Abstract | Publisher Full Tex

105. Biter $A B$, Lee J, Sung N, et al:: Functional analysis of conserved cis- and transelements in the Hsp104 protein disaggregating machine. J Struct Biol. 2012; 179(2): $172-80$.

PubMed Abstract | Publisher Full Text | Free Full Text

106. Zeymer $\mathrm{C}$, Fischer $\mathrm{S}$, Reinstein J: trans-Acting arginine residues in the $\mathrm{AAA}+$ chaperone $\mathrm{ClpB}$ allosterically regulate the activity through inter- and intradomain communication. J Biol Chem. 2014; 289(47): 32965-76. PubMed Abstract | Publisher Full Text | Free Full Text

107. Parsell DA, Kowal AS, Lindquist S: Saccharomyces cerevisiae Hsp104 protein Purification and characterization of ATP-induced structural changes. J Biol Chem. 1994; 269(6): 4480-7. PubMed Abstract

108. Watanabe $\mathrm{YH}$, Motohashi K, Yoshida M: Roles of the two ATP binding sites of ClpB from Thermus thermophilus. J Biol Chem. 2002; 277(8): 5804-9. PubMed Abstract | Publisher Full Text

109. Motohashi $\mathrm{K}$, Watanabe $\mathrm{Y}$, Yohda $\mathrm{M}$, et al.: Heat-inactivated proteins are rescued by the DnaK.J-GrpE set and CIpB chaperones. Proc Natl Acad Sci U S A. 1999; 96(13): 7184-9.

PubMed Abstract | Publisher Full Text | Free Full Text

110. Goloubinoff $P$, Mogk $A, Z v i$ AP, et al:: Sequential mechanism of solubilization and refolding of stable protein aggregates by a bichaperone network. Proc Natl Acad Sci U S A. 1999; 96(24): 13732-7. PubMed Abstract | Publisher Full Text | Free Full Text

111. Zolkiewski M: ClpB cooperates with DnaK, DnaJ, and GrpE in suppressing protein aggregation. A novel multi-chaperone system from Escherichia coli. J Biol Chem. 1999; 274(40): 28083-6. PubMed Abstract | Publisher Full Text

112. Sweeny EA, Jackrel ME, Go MS, et al: The Hsp104 N-terminal domain enables disaggregase plasticity and potentiation. Mol Cell. 2015; 57(5): 836-49. PubMed Abstract | Publisher Full Text | Free Full Text

113. Haslberger T, Weibezahn J, Zahn R, et al:: M domains couple the ClpB threading motor with the DnaK chaperone activity. Mol Cell. 2007; 25(2): 247-60. PubMed Abstract | Publisher Full Text

114. Sielaff B, Tsai FT: The M-domain controls Hsp104 protein remodeling activity in an Hsp70/Hsp40-dependent manner. J Mol Biol. 2010; 402(1): 30-7. PubMed Abstract | Publisher Full Text | Free Full Text
115. Miot M, Reidy M, Doyle SM, et al.: Species-specific collaboration of heat shock proteins (Hsp) 70 and 100 in thermotolerance and protein disaggregation. Proc Natl Acad Sci U S A. 2011; 108(17): 6915-20.

PubMed Abstract | Publisher Full Text | Free Full Text

116. Mogk A, Kummer E, Bukau B: Cooperation of Hsp70 and Hsp100 chaperone machines in protein disaggregation. Front Mol Biosci. 2015; 2: 22. PubMed Abstract | Publisher Full Text | Free Full Text

117. Doyle SM, Genest $O$, Wickner S: Protein rescue from aggregates by powerful molecular chaperone machines. Nat Rev Mol Cell Biol. 2013; 14(10): $617-29$

PubMed Abstract | Publisher Full Tex

118. Winkler J, Tyedmers J, Bukau B, et al:: Chaperone networks in protein disaggregation and prion propagation. J Struct Biol. 2012; 179(2): 152-60. PubMed Abstract | Publisher Full Text

119. Biter $A B$, Lee $S$, Sung $N$, et al:: Structural basis for intersubunit signaling in a protein disaggregating machine. Proc Natl Acad Sci U S A. 2012; 109(31): $12515-20$.

PubMed Abstract | Publisher Full Text | Free Full Text

120. F Weibezahn J, Tessarz $\mathrm{P}$, Schlieker $\mathrm{C}$, et al.: Thermotolerance requires refolding of aggregated proteins by substrate translocation through the central pore of ClpB. Cell. 2004; 119(5): 653-65. PubMed Abstract | Publisher Full Text | F1000 Recommendation

121. Lum R, Tkach JM, Vierling $E$, et al:: Evidence for an unfolding/threading mechanism for protein disaggregation by Saccharomyces cerevisiae Hsp104. J Biol Chem. 2004; 279(28): 29139-46. PubMed Abstract | Publisher Full Tex

122. Clarke AK, Eriksson MJ: The truncated form of the bacterial heat shock protein ClpB/HSP100 contributes to development of thermotolerance in the cyanobacterium Synechococcus sp. strain PCC 7942. J Bacteriol. 2000; 182(24) 7092-6.

PubMed Abstract | Publisher Full Text | Free Full Text

123. Beinker $\mathrm{P}$, Schlee $\mathrm{S}$, Groemping $\mathrm{Y}$, et al:: The $\mathbf{N}$ terminus of $\mathrm{ClpB}$ from Thermus thermophilus is not essential for the chaperone activity. J Biol Chem. 2002; 277(49): 47160-6. PubMed Abstract | Publisher Full Tex

124. Hung GC, Masison DC: N-terminal domain of yeast Hsp104 chaperone is dispensable for thermotolerance and prion propagation but necessary for curing prions by Hsp104 overexpression. Genetics. 2006; 173(2): 611-20. PubMed Abstract | Publisher Full Text | Free Full Text

125. Lum R, Niggemann M, Glover JR: Peptide and protein binding in the axial channel of Hsp104. Insights into the mechanism of protein unfolding. $J$ BiO Chem. 2008; 283(44): 30139-50.

PubMed Abstract | Publisher Full Text | Free Full Text

126. Barnett ME, Zolkiewska A, Zolkiewski M: Structure and activity of ClpB from Escherichia coli. Role of the amino-and -carboxyl-terminal domains. $J$ Biol Chem. 2000; 275(48): 37565-71. PubMed Abstract | Publisher Full Text | Free Full Text

127. Barnett ME, Nagy M, Kedzierska S, et al:: The amino-terminal domain of ClpB supports binding to strongly aggregated proteins. J Biol Chem. 2005; 280(41): $34940-5$

PubMed Abstract | Publisher Full Text

128. Park SK, Kim KI, Woo KM, et al:: Site-directed mutagenesis of the dual translational initiation sites of the clpB gene of Escherichia coli and characterization of its gene products. J Biol Chem. 1993; 268(27): 20170-4. PubMed Abstract

129. Li J, Sha B: Crystal structure of the E. coli Hsp100 ClpB N-terminal domain. Structure. 2003; 11(3): 323-8.

PubMed Abstract | Publisher Full Text

130. Tanaka N, Tani $\mathrm{Y}$, Hattori $\mathrm{H}$, et al.: Interaction of the $\mathrm{N}$-terminal domain of Escherichia coli heat-shock protein ClpB and protein aggregates during chaperone activity. Protein Sci. 2004; 13(12): 3214-21. PubMed Abstract | Publisher Full Text | Free Full Text

131. Chow IT, Barnett ME, Zolkiewski M, et al.: The N-terminal domain of Escherichia coli ClpB enhances chaperone function. FEBS Lett. 2005; 579(20): 4242-8. PubMed Abstract | Publisher Full Text

132. Winkler J, Tyedmers J, Bukau B, et al.: Hsp70 targets Hsp100 chaperones to substrates for protein disaggregation and prion fragmentation. $J$ Cell Biol. 2012; 198(3): 387-404.

PubMed Abstract | Publisher Full Text | Free Full Text

133. Erjavec N, Larsson L, Grantham J, et al.: Accelerated aging and failure to segregate damaged proteins in Sir2 mutants can be suppressed by overproducing the protein aggregation-remodeling factor Hsp104p. Genes Dev. 2007; 21(19): 2410-21.

PubMed Abstract | Publisher Full Text | Free Full Text

134. Tessarz $P$, Schwarz M, Mogk A, et al.: The yeast AAA $^{+}$chaperone Hsp104 is part of a network that links the actin cytoskeleton with the inheritance of damaged proteins. Mol Cell Biol. 2009; 29(13): 3738-45. PubMed Abstract | Publisher Full Text | Free Full Text

135. F Wang F, Brown EC, Mak G, et al.: A chaperone cascade sorts proteins for posttranslational membrane insertion into the endoplasmic reticulum. $\mathrm{Mol}$ Cell. 2010; 40(1): 159-71.

PubMed Abstract | Publisher Full Text | Free Full Text | F1000 Recommendation 
136. Johnson CR, Weems AD, Brewer JM, et al:: Cytosolic chaperones mediate quality control of higher-order septin assembly in budding yeast. Mol Biol Cell. 2015; 26(7): 1323-44.

PubMed Abstract | Publisher Full Text | Free Full Text

137. Csermely $\mathrm{P}:$ Chaperone overload is a possible contributor to 'civilization diseases'. Trends Genet. 2001; 17(12): 701-4. PubMed Abstract | Publisher Full Text

138. F Gidalevitz T, Ben-Zvi A, Ho KH, et al.: Progressive disruption of cellular protein folding in models of polyglutamine diseases. Science. 2006; 311(5766)
1471-4.

PubMed Abstract | Publisher Full Text | F1000 Recommendation

139. F Balch WE, Morimoto RI, Dillin A, et al:: Adapting proteostasis for disease intervention. Science. 2008; 319(5865): 916-9.

PubMed Abstract | Publisher Full Text | F1000 Recommendation

140. Lindquist SL, Kelly JW: Chemical and biological approaches for adapting proteostasis to ameliorate protein misfolding and aggregation diseases: progress and prognosis. Cold Spring Harb Perspect Biol. 2011; 3(12): pii: a004507. PubMed Abstract | Publisher Full Text | Free Full Text 


\section{Open Peer Review}

\section{Current Peer Review Status:}

\section{Editorial Note on the Review Process}

Faculty Reviews are review articles written by the prestigious Members of Faculty Opinions. The articles are commissioned and peer reviewed before publication to ensure that the final, published version is comprehensive and accessible. The reviewers who approved the final version are listed with their names and affiliations.

\section{The reviewers who approved this article are:}

\section{Version 1}

\section{Hays Rye}

Department of Biochemistry and Biophysics, Texas A\&M University, College Station, TX, USA

Competing Interests: No competing interests were disclosed.

\section{Jose Barral}

Neuroscience and Cell Biology, University of Texas Medical Branch, Galveston, TX, USA

Competing Interests: No competing interests were disclosed.

The benefits of publishing with F1000Research:

- Your article is published within days, with no editorial bias

- You can publish traditional articles, null/negative results, case reports, data notes and more

- The peer review process is transparent and collaborative

- Your article is indexed in PubMed after passing peer review

- Dedicated customer support at every stage

For pre-submission enquiries, contact research@f1000.com 